\title{
Aplikasi Agenda Kegiatan Pada BPSDMP Komunikasi Dan Informatika Banjarmasin Berbasis Web
}

\author{
Herpendi $^{1)}$, Resni Habibah ${ }^{2)}$ \\ 1)2) Jurusan Teknik Informatika, Politeknik Negeri Tanah Laut \\ Jl.A.Yani Km 6 Pelaihari Tanah Laut Kalimantan Selatan \\ ${ }^{1)}$ herpendi@gmail.com \\ ${ }^{2)}$ resnihabibah15@gmail.com
}

\begin{abstract}
Abstrak
Balai Pengembangan Sumber Daya Manusia dan Penelitian (BPSDMP) Komunikasi dan Informatika Banjarmasin merupakan instansi yang berfokus pada kegiatan penelitian dan pengembangan di bidang komunikasi dan informatika dan memiliki tiga struktur organisasi yaitu Subbagian Tata Usaha, Seksi Pengembangan Sumber Daya Manusia dan Seksi Penelitian Komunikasi dan Informatika. BPSDMP Komunikasi dan Informatika Banjarmasin memiliki kegiatan rutin setiap tahun yaitu kegiatan literasi TIK, seminar hasil penelitian, sertifikasi nasional berbasis SKKNI, digital talent, dan rapat. Pencatatan agenda kegiatan dan pelaporan hasil kegiatan yang berjalan saat ini masih dikerjakan dengan cara manual dan sederhana. Untuk mengatasi masalah tersebut maka dibangun suatu Aplikasi Agenda Kegiatan Berbasis Web yang diharapkan dapat mempermudah pekerjaan Subbagian Tata Usaha, Seksi Pengembangan SDM, Seksi Penelitian Kominfo karena sudah terkomputerisasi untuk mencetak hasil laporan dan mempermudah apabila ingin melihat data-data kegiatan yang telah dikelola sekaligus dapat mengetahui apabila ada kegiatan yang terlupa dan belum terlaksana. Aplikasi Agenda Kegiatan Berbasis Web dibuat dengan menggunakan bahasa pemrograman PHP, HTML, CSS dan Javascript. Serta dirancang menggunakan Entity Relationship Diagram, Data Flow Diagram dan Flowchart.
\end{abstract}

Kata Kunci : Aplikasi, Agenda Kegiatan, Website, ERD, DFD.

\begin{abstract}
Balai Pengembangan Sumber Daya Manusia dan Penelitian (BPSDMP) Komunikasi dan Informatika Banjarmasin is an agency that focuses on research and development activities in the field of communication and informatics and has three organizational structures namely Administrative Subdivision, Human Resources Development Section, Research Section for Communication and Information Technology. BPSDMP Komunikasi dan Informatika Banjarmasin has routine activities every year, namely ICT Literacy activities, Research results seminar, SKKNI-based national certification, Digital talent, and Meetings. The recording of the activity agenda and reporting on the results of the activities that are currently running are still done manually and simply. To overcome this problem then built an expected Web Based Activity Agenda Application can simplify the work of Administration Subdivision, HR Development Section, Research and Communication Section of Information and Communication Technology because it's computerized to print report results and make it easier if you want to see the data of activities that have been managed at the same time can find out if there are activities that are forgotten and have not been implemented. Application Activity AgendaService is made using a programming language PHP, HTML, CSS and Javascript. And designed to use Entity Relationship Diagram, Data Flow Diagram and Flowchart.
\end{abstract}

Keywords: Application, Activity Agenda, Website, ERD, DFD. 


\section{PENDAHULUAN}

Balai Pengembangan Sumber Daya Manusia dan Penelitian (BPSDMP) Komunikasi dan Informatika Banjarmasin adalah instansi yang berfokus pada kegiatan penelitian dan pengembangan di bidang komunikasi dan informatika. BPSDMP Kominfo Banjarmasin memiliki tiga struktur organisasi yaitu Subbagian Tata Usaha, Seksi Pengembangan Sumber Daya Manusia, Seksi Penelitian Komunikasi dan Informatika. BPSDMP Komunikasi dan Informatika Banjarmasin memiliki kegiatan rutin setiap tahun yaitu kegiatan Literasi TIK, Seminar hasil penelitian, setifikasi nasional berbasis SKKNI, Digital talent, dan Rapat. Adapun kepanitiaan kegiatan rutin tersebut dipegang oleh ketiga subbagian secara bergantian.

Subbagian Tata Usaha, Seksi Pengembangan Sumber Daya Manusia, Seksi Penelitian Komunikasi dan Informatika masih secara manual mencatat kegiatan rutin setiap tahun untuk melaporkan kepada Kepala Balai. Adapun permasalahan yang didapat yaitu adanya kegiatan yang lupa dilaksanakan, sulitnya mencari berkas data-data kegiatan yang telah dibuat sebelumnya. Maka dari itu BPSDMP Komunikasi dan Informatika membutuhkan sebuah aplikasi berbasis web yang dapat membantu ketiga subbagian untuk menginputkan data-data kegiatan rutin setiap tahun. Data-data kegiatan rutin tersebut tersusun lebih rapi dan lebih mudah dalam pencarian data.

Berdasarkan permasalahan tersebut maka penulis mengangkat judul "Aplikasi Agenda Kegiatan Pada BPSDMP Komunikasi dan Informatika Banjarmasin Berbasis Web" untuk memudahkan dan mengurangi terjadinya masalah yang disebabkan banyaknya agenda kegiatan yang terlupa, serta dapat mempermudahkan pengarsipan dan akan lebih efektif dari segi waktu pemrosesan laporan.

\section{TINJAUAN PUSTAKA}

\subsection{Aplikasi}

Aplikasi berasal dari kata application yaitu bentuk benda dari kata kerja to apply yang dalam bahasa Indonesia berarti pengolah. Secara istilah, aplikasi komputer adalah suatu sub kelas perangkat lunak komputer yang menggunakan kemampuan computer langsung untuk melakukan suatu tugas yang diinginkan pemakai (Herpendi, 2017).

\subsection{Agenda Kegiatan}

Pada dasarnya agenda kegiatan mencakup pengurutan aktivitas, pengalokasian aktivitas pada fasilitas dan pemetaan aktivitas menurut urutan waktu. Tujuan agenda kegiatan adalah meningkatkan efektivitas dan efisiensi waktu, mengurangi terjadinya keterlambatan (Raharja, Lutfiani, \& Wardana, 2018).

\subsection{Website}

Website atau situs dapat diartikan sebagai kumpulan halaman yang menampilkan informasi data teks, data gambar diam atau gerak, data animasi, suara, video dan atau gabungan dari semuanya, baik yang bersifat statis maupun dinamis yang membentuk satu rangkaian bangunan yang saling terkait dimana masing-masing dihubungkan dengan jaringan-jaringan halaman (hyperlink). Bersifat statis apabila isi informasi website tetap, jarang berubah, dan isi informasinya searah hanya dari pemilik website. Bersifat dinamis apabila isi informasi website selalu berubah-ubah, dan isi informasinya interaktif dua arah berasal dari pemilik serta pengguna website (Riyadi, Retnadi, \& Supriatna, 2012).

\subsection{PHP (Perl Hypertext Processor)}

PHP merupakan bahasa pemrograman pada sisi server yang memperbolehkan programmer menyisipkan perintah - perintah perangkat lunak web server (Apache, IIS, atau apapun) akan dieksekusi sebelum perintah itu dikirim oleh halaman ke browser yang me-request-nya, contohnya adalah bagaimana memungkinkannya memasukkan tanggal sekarang pada sebuah halaman web setiap kali tampilan tanggal dibutuhkan. Sesuai dengan fungsinya yang berjalan di sisi server maka PHP adalah bahasa pemrograman yang digunakan untuk membangun teknologi web application (Februariyanti \& Zuliarso, 2012). 


\subsection{HTML (Hyper text Markup Language)}

HyperText Markup Language merupakan suatu metode untuk mengimplementasikan konsep hypertext dalam suatu naskah atau dokumen. HTML sendiri bukan tergolong pada suatu bahasa pemrograman karena sifatnya yang hanya memberikan tanda (marking up) pada suatu naskah teks dan bukan sebagai program (Puspitasari, 2016).

\subsection{MySQL}

MySQL adalah sebuah implementasi dari sistem manajemen basisdata relasional (RDBMS) yang didistribusikan secara gratis dibawah lisensi GPL (General Public License). Setiap pengguna dapat secara bebas menggunakan MySQL, namun dengan batasan perangkat lunak tersebut tidak boleh dijadikan produk turunan yang bersifat komersial. MySQL sebenarnya merupakan turunan salah satu konsep utama dalam basisdata yang telah ada sebelumnya. SQL (Structured Query Language) adalah sebuah konsep pengoperasian basisdata, terutama untuk pemilihan atau seleksi dan pemasukan data, yang memungkinkan pengoperasian data dikerjakan dengan mudah secara otomatis. Kehandalan suatu sistem basisdata (DBMS) dapat diketahui dari cara kerja pengoptimasi-nya dalam melakukan proses perintah-perintah SQL yang dibuat oleh pengguna maupun program-program aplikasi yang memanfaatkannya. Sebagai peladen basis data, MySQL mendukung operasi basisdata transaksional maupun operasi basisdata nontransaksional. Pada modus operasi nontransaksional, MySQL dapat dikatakan unggul dalam hal unjuk kerja dibandingkan perangkat lunak peladen basisdata kompetitor lainnya (Februariyanti \& Zuliarso, 2012).

\section{$2.7 \quad$ ERD}

Entity Relationship Diagram (ERD) dikembangkan berdasarkan teori himpunan dalam bidang matematika. ERD digunakan untuk pemodelan basis data relasional. Sehingga jika penyimpanan basis data menggunakan database management system (ODBMS) maka perancangan basis data tidak perlu menggunakan ERD. ERD memiliki beberapa aliran notasi seperti notasi Chen (dikembangkan oleh Peter Chen), Berker (dikembangkan oleh Richard Barker, Ian Palmer, Harry Ellis), notasi Crow's Foot, dan beberapa notasi lain. Namun yang banyak digunakan adalah notasi dari Chen (Rosa \& Shalahuddin, 2013).

\subsection{DFD}

Data flow diagram (DFD) atau bagan alir data digunkan untuk menggambarkan sistem secara logika tanpa memperhatikan lingkungan fisik dimana data tersebut mengalir atau akan disimpan. Data flow diagram merupakan alat pengembangan arus data dalam sistem secara terstruktur dan jelas (Sovia \& Febio, 2011).

\section{METODE PENGEMBANGAN SISTEM}

Metode pengembangan sistem pada pembuatan aplikasi amandemen laporan survey ekspor ini adalah metode waterfall. Menurut Rosa dan Shalahuddin (2013), metode waterfall adalah model SDLC (Software Developmentt Life Cycle) yang paling sederhana. Model ini hanya cocok untuk pengembangan perangkat lunak dengan spesifikasi yang tidak berubah-rubah. Motode ini menyediakan pendekatan alur hidup perangkat lunak secara sekuensial atau terurut dimulai dari analisis, desain, pengodean, pengujian, dan tahap pendukung (support). Metode waterfall dapat dilihat pada Gambar 1.

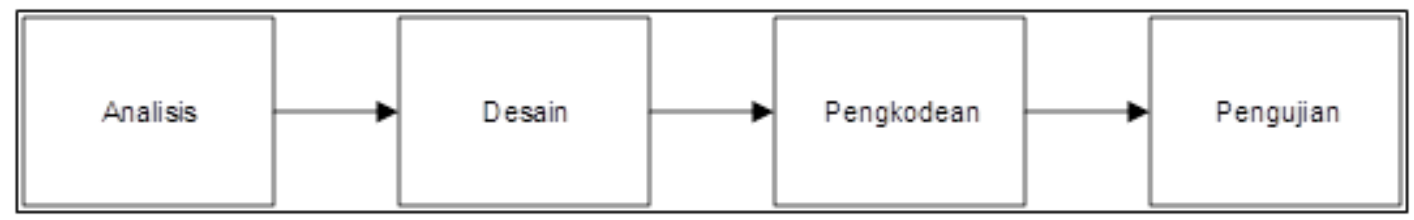

Gambar 1. Metode waterfall 
1. Analisis

Proses pengumpulan data dilakukan dengan wawancara, untuk menganalisis pemahaman perangkat lunak yang diinginkan pengguna. Wawancara dilakukan dengan pembimbing lapangan sekaligus pimpinan cabang perusahaan. Data yang didapatkan yaitu rancangan aplikasi yang diinginkan perusahaan.

\section{Desain}

Desain sistem melibatkan identifikasi dan rancangan sistem yang di inginkan. Proses perancangan sistem menggunakan ERD, DFD, dan flowchart.

\section{Pengodean}

Pada tahap ini adalah penerapan desain yang telah dirancang ke dalam program perangkat lunak. Program perangkat lunak yang digunakan adalah HTML, PHP, Database MySQL, CSS.

\section{Pengujian}

Pengujian berfokus pada perangkat lunak secara fungsional. Pada tahap pengujian dilakukan untuk memastikan bahwa semua bagian sudah diuji dan dapat berjalan sesuai yang diinginkan serta sesuai dengan desain yang telah dirancang. Proses ini dilakukan untuk menghindari adanya kesalahan atau error pada sistem yang telah dibuat.

\section{HASIL DAN PEMBAHASAN}

\subsection{Analisis Sistem}

\subsubsection{Analisis Sistem yang Berjalan}

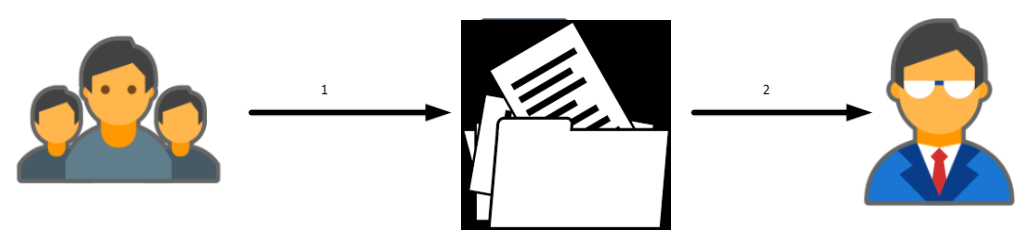

Gambar 2. Analisis sistem yang berjalan

Gambar 2 merupakan analisis sistem yang berjalan saat ini masih manual dan sederhana untuk mencatat semua agenda kegiatan yang dibuat oleh masing-masing bagian yaitu Subbagian Tata Usaha, Seksi Pengembangan SDM, Seksi Penelitian Kominfo untuk melaporkan data kegiatan kepada Kepala Balai. Analisis sistem ini bertujuan untuk membuat sistem yang baru agar data disimpan lebih efektif dan efisien.

\subsubsection{Analisis Sistem yang Diusulkan}

Gambar 3 merupakan sistem yang diusulkan yaitu Subbagian Tata Usaha, Seksi Pengembangan SDM, Seksi Penelitian Kominfo menginputkan data agenda kegiatan dan subagenda ke aplikasi agenda kegiatan agar seluruh data yang diinputkan oleh tiga bagian seksi langsung dapat dilihat oleh Kepala Balai, Kepala Balai menginputkan data admin dan data pegawai ke aplikasi agenda kegiatan, data admin merupakan pegawai yang telah diinputkan sebelumnya di data pegawai karena admin merupakan pegawai Subbagian Tata Usaha, Seksi Pengembangan SDM, Seksi Penelitian Kominfo, Kepala Balai menerima informasi data agenda yang telah diinputkan Subbagian Tata Usaha, Seksi Pengembangan SDM, Seksi Penelitian Kominfo.

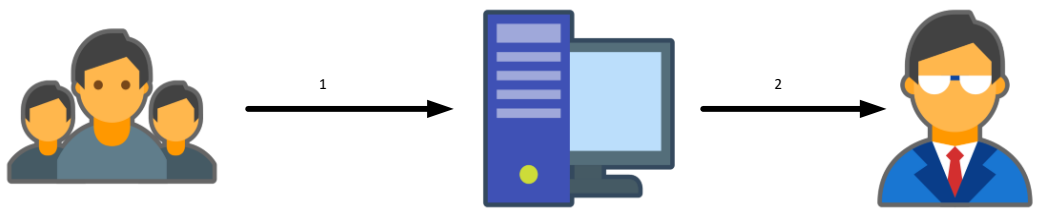




\subsection{Perancangan Sistem}

Gambar 3. Sistem yang diusulkan

\subsubsection{Entity Relationship Diagram (ERD)}

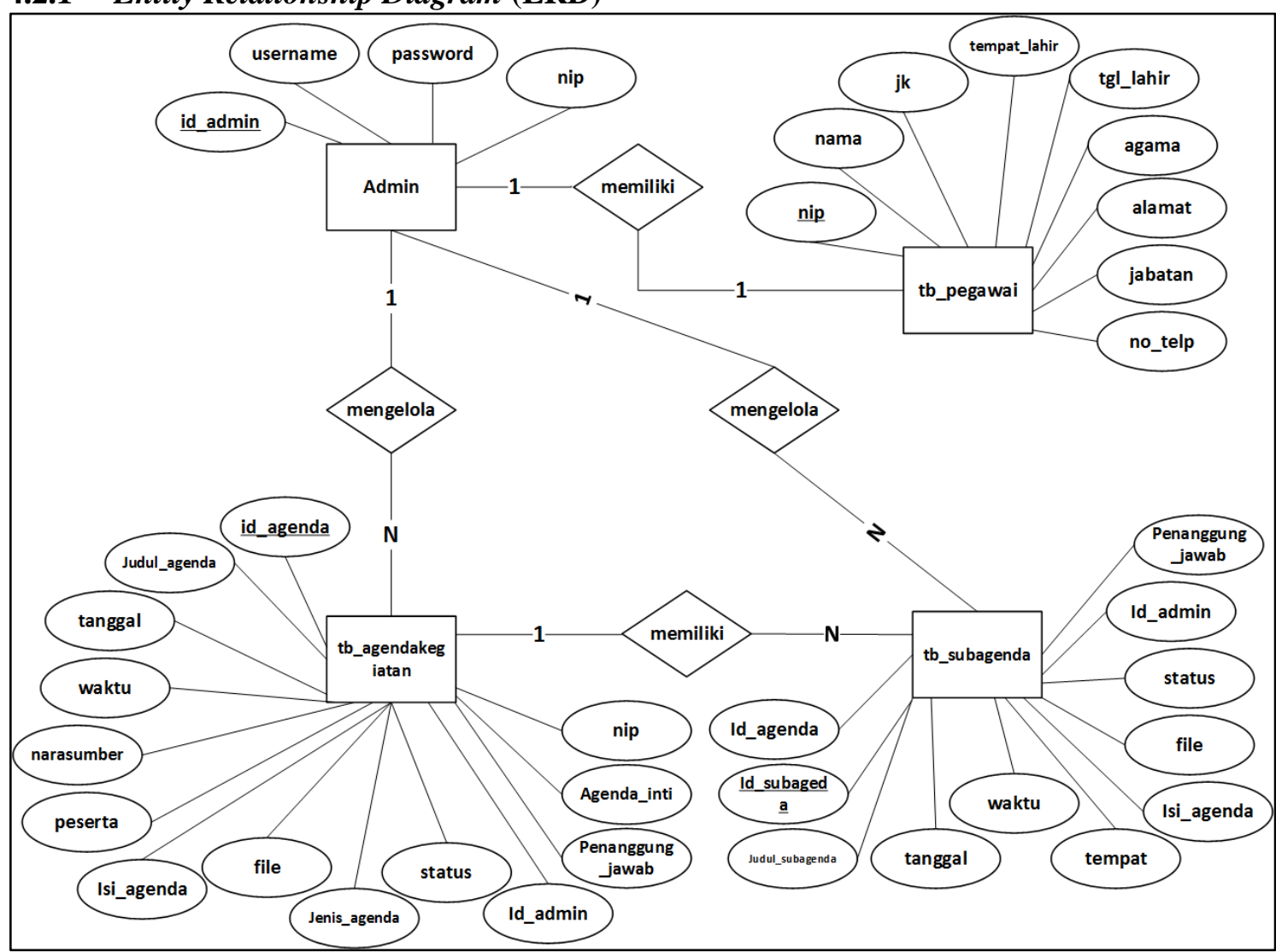

Gambar 4. Entity Relationship Diagram (ERD)

Dari gambar diagram diatas, diagram ERD ini menggambarkan tabel yang ada didalam satu database dimana satu admin memiliki satu pegawai, satu admin bisa mengelola banyak agenda_kegiatan, satu admin bisa mengelola banyak subagenda, subagenda hanya memiliki satu agenda_kegiatan, agenda_kegiatan bisa memiliki banyak subagenda.

\subsubsection{Diagram Konteks}

Gambar 5 mendeskripsikan diagram konteks yang menggambarkan Aplikasi ini memiliki 2 pengguna yaitu Admin dan Super Admin. Admin dapat mengelola data agenda dan sub agenda serta mendapatkan info agenda dan sub agenda. Sedangkan super admin dapat mengelola data admin dan pegawai serta mendapatkan info admin, pegawai, agenda dan sub agenda.

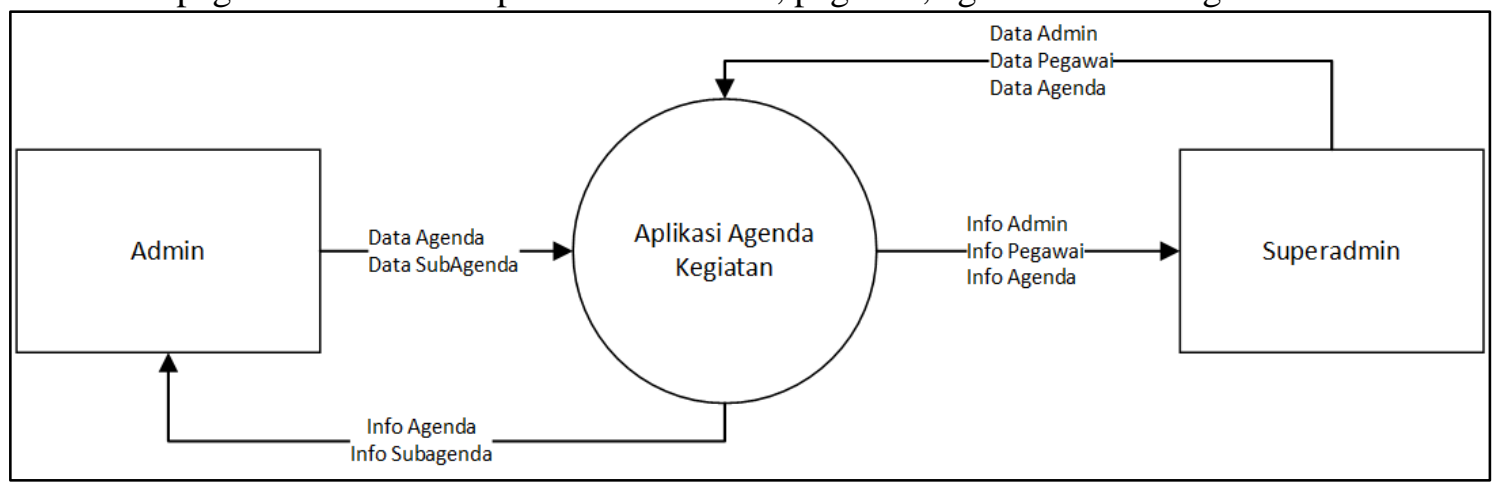

Gambar 5. Diagram konteks 


\subsection{Implementasi Antarmuka}

Implementasi dari Sistem Informasi Peminjaman Mobil dan Service Motor pada PT. Sumber Alfaria Trijaya, Tbk Branch Banjarmasin Berbasis Web sebagai berikut:

\subsubsection{Tampilan Halaman Login}

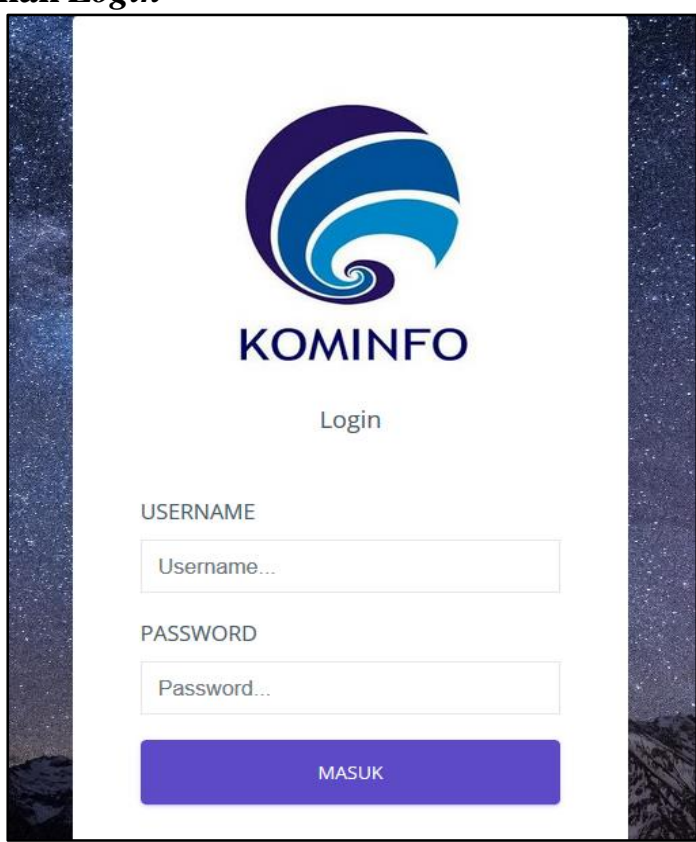

Gambar 6. Tampilan form login

Gambar 6 merupakan tampilan form login, pada form login admin dan superadmin wajib mengisi username dan password terlebih dulu, apabila username dan password yang dimasukan benar maka akan masuk kehalaman selanjutnya.

\subsubsection{Tampilan Beranda Admin}

Gambar 7 merupakan tampilan beranda admin ketika masuk ke halaman beranda admin maka akan tampil menu beranda, menu data agenda yaitu tampilan tabel data agenda yang telah diinputkan oleh admin yang login, notifikasi agenda yang belum dilaksanakan dan tampilan pemberitahuan agenda yang sudah dilaksanakan, agenda yang belum dilaksanakan, total agenda, dan total subagenda. Dihalaman beranda admin terdapat menu logout yang terletak diujung kanan halaman, admin bisa langsung logout jika ingin keluar dari halaman beranda admin.

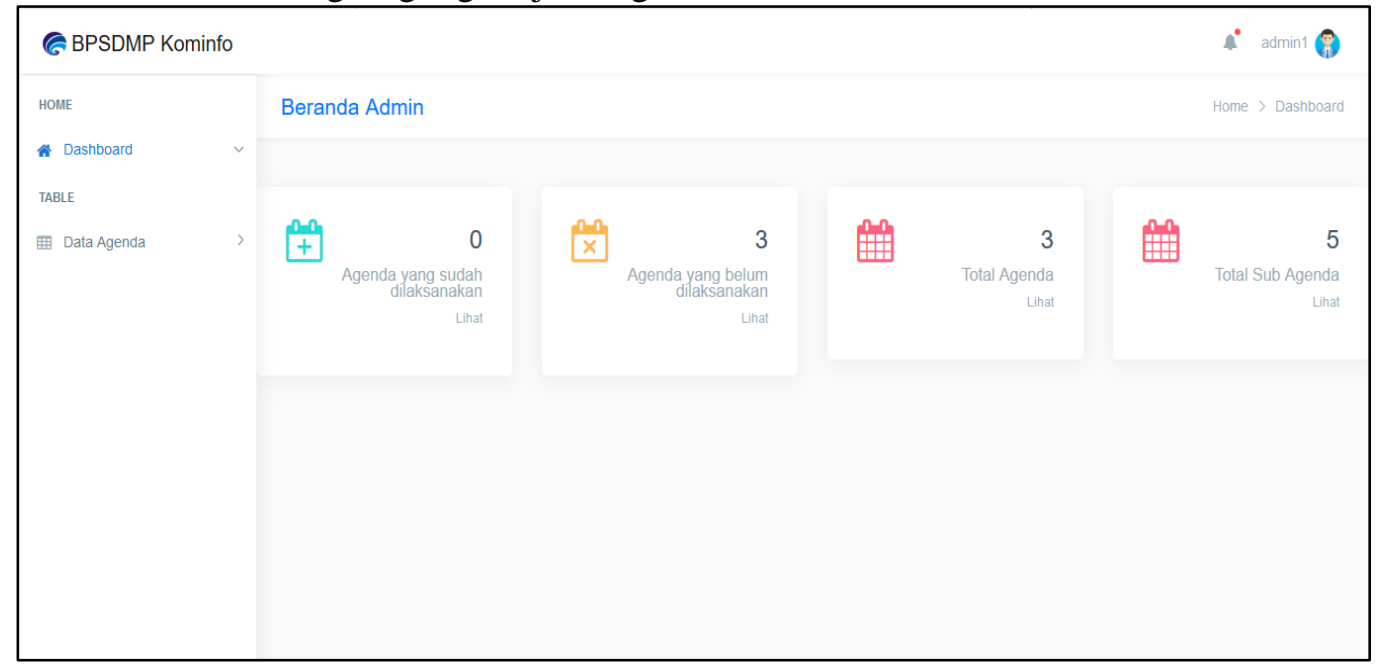

Gambar 7. Tampilan beranda admin 


\subsubsection{Tampilan Form Data Agenda}

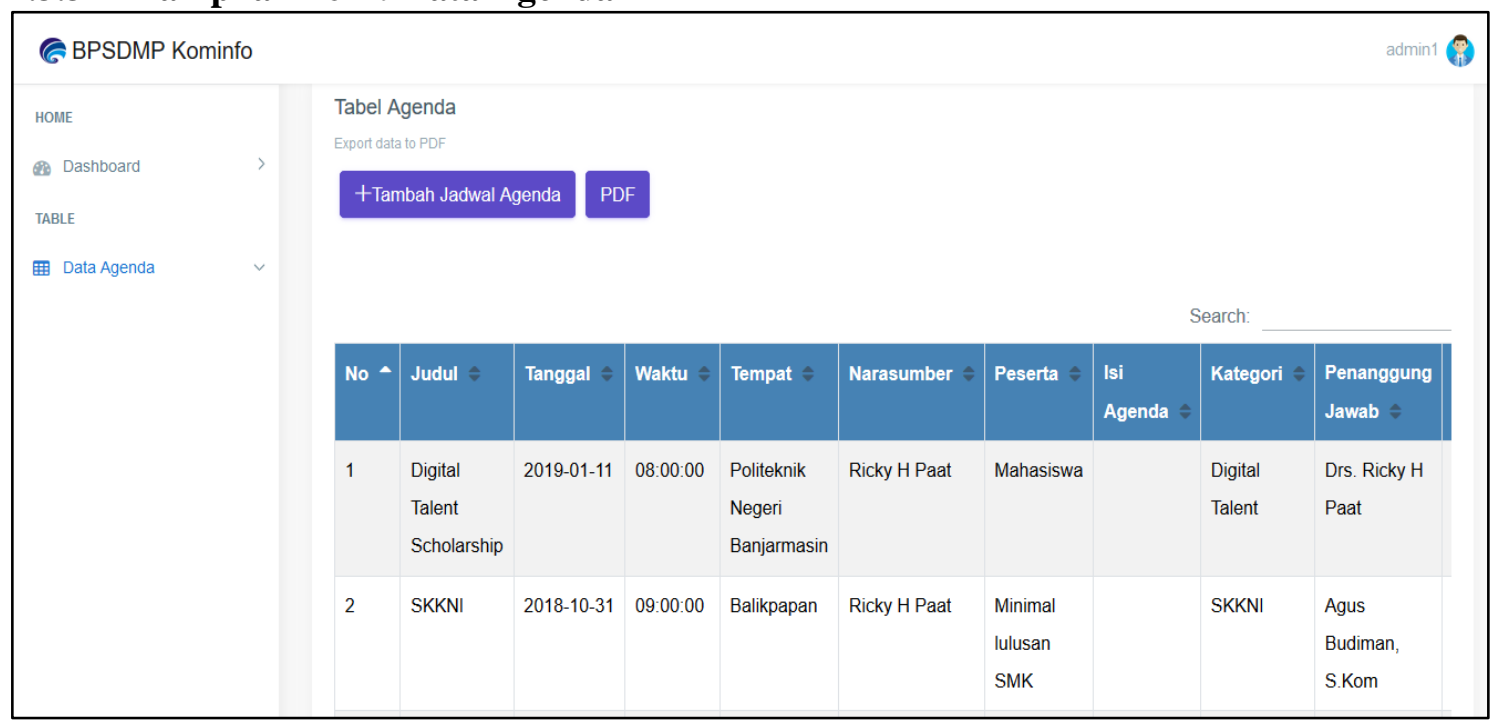

Gambar 8. Tampilan form data agenda

Gambar 8 menunjukan tampilan data agenda dimana dihalaman data agenda terdapat menu Tambah jadwal agenda, menu Cetak PDF data agenda dan menu search data agenda. Admin dapat menambah data agenda, mengubah data agenda yang sudah ada, menghapus data agenda, mencari data agenda dan mencetak data agenda. Pada halaman data agenda juga terdapat menu logout diujung kanan halaman tersebut. Pada halaman data agenda menampilkan tabel no, judul, tanggal, waktu, tempat, narasumber, peserta, isi agenda, kategori, penanggung jawab, detail subagenda, tambah data subagenda dan button aksi hapus dan edit data agenda.

\subsubsection{Tampilan Form Data Subagenda}

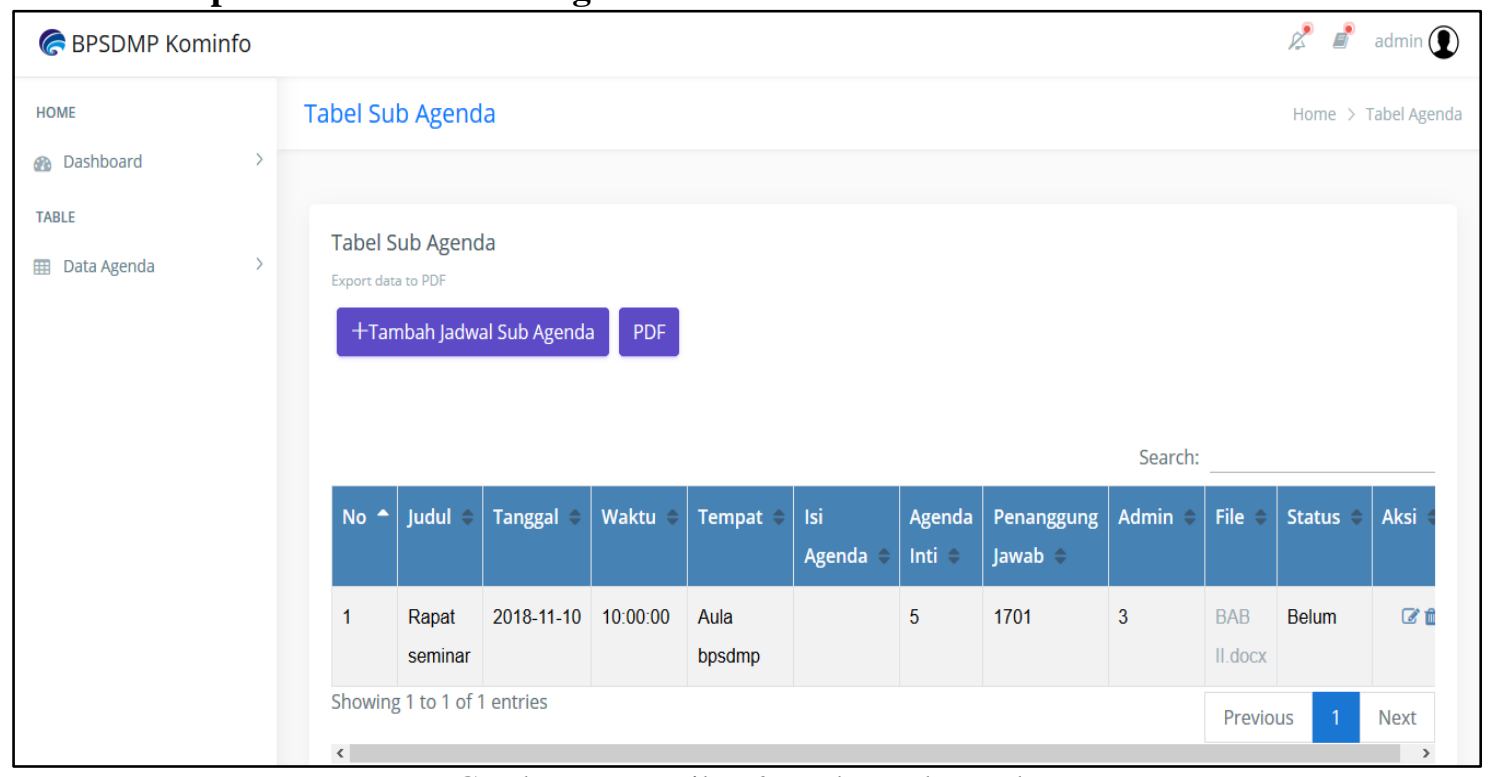

Gambar 9. Tampilan form data subagenda

Gambar 9 merupakan tampilan data subagenda pada tampilan data subagenda admin bisa mengedit, menghapus, mencari dan mencetak data subagenda. Ditampilan data subagenda terdapat menu beranda, menu data agenda, menu tambah datasub agenda, menu cetak PDF dan menu logout apabila admin ingin keluar dari halaman data subagenda. 


\subsubsection{Tampilan Form Data Admin}

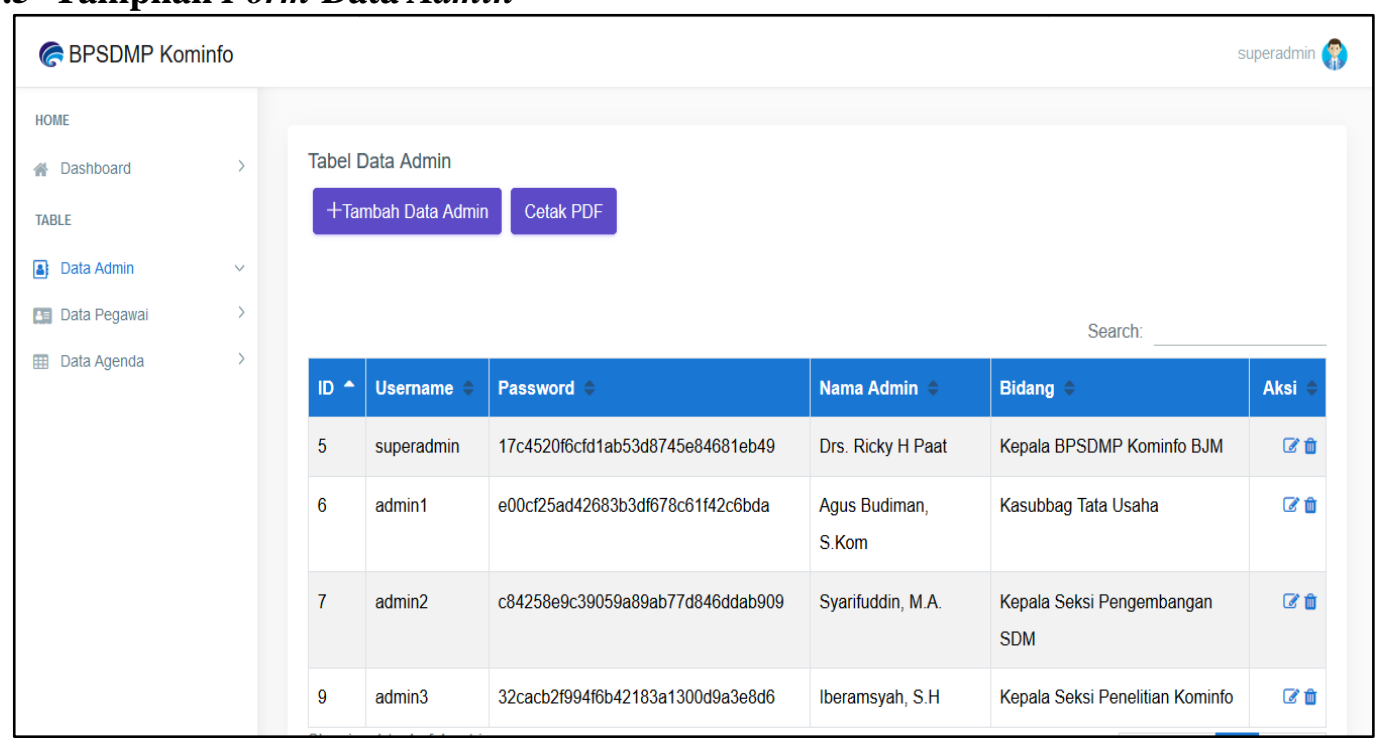

Gambar 10. Tampilan form data admin

Gambar 10 merupakan tampilan data admin pada tampilan data admin tedapat menu beranda, menu data admin, menu data pegawai, menu tambah data admin, cetak PDF data admin, menu logout. Pada tampilan data admin superadmin bisa mengedit, menghapus, mencari, dan mencetak data admin. Ditampilan tabel data admin terdapat tabel ID, username, password, nama admin yang dimasukkan merupakan pegawai yang telah diinputkan didata pegawai dan aksi edit dan hapus.

\subsubsection{Tampilan Form Data Pegawai}

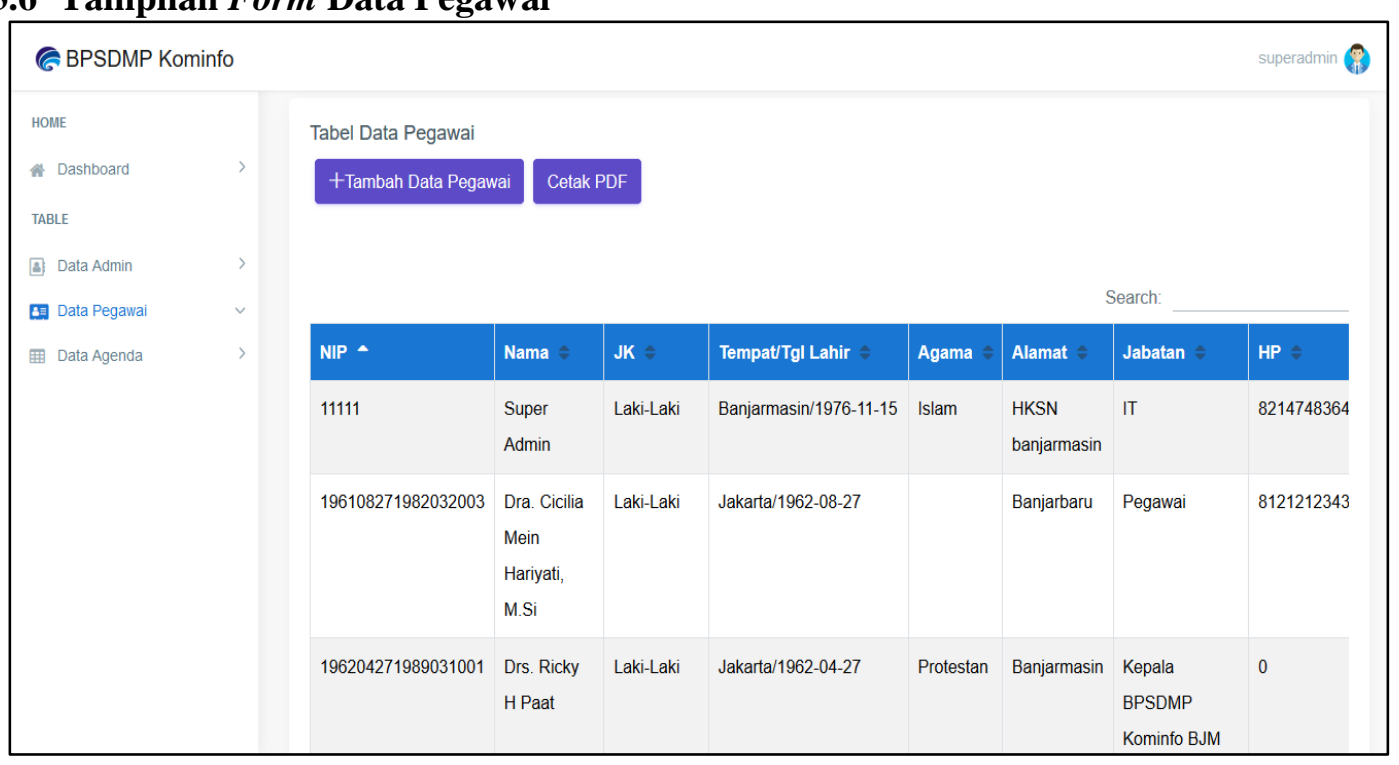

Gambar 11. Tampilan data pegawai

Gambar 11 merupakan tampilan data pegawai pada tampilan data pegawai terdapat menu data admin, menu data pegawai, menu data agenda, menu logout apabila superadmin ingin keluar dari halaman data pegawai. Dihalaman data pegawai terdapat menu Tambah data pegawai dan menu cetak PDF data pegawai. Superadmin bisa mengedit, menghapus, mencari, dan mencetak data pegawai yang telah diinputkan. Ditabel data pegawai menampilkan nip, nama, jk, tempat tanggal lahir, agama, alamat, jabatan, no hp dan juga tabel aksi yaitu button edit dan hapus. 


\section{KESIMPULAN}

Kesimpulan yang dapat diambil adalah telah dibuat Aplikasi Agenda Kegiatan diharapkan dapat memudahkan Subbagian Tata Usaha, Seksi Pengembangan SDM, Seksi Penelitian Kominfo untuk melaporkan kepada Kepala Balai tentang hasil kegiatan yang telah dirapatkan yang sebelumnya menggunakan cara manual yaitu dengan mencatat hasil kegiatan dan melaporkan kepada Kepala Balai.

Dengan adanya aplikasi agenda kegiatan diharapkan dapat mempermudah pekerjaan Subbagian Tata Usaha, Seksi Pengembangan SDM, Seksi Penelitian Kominfo karena sudah terkomputerisasi untuk mencetak hasil laporan dan mempermudah apabila ingin melihat data-data kegiatan yang telah dikelola sekaligus dapat mengetahui apabila ada kegiatan yang terlupa dan belum terlaksana.

\section{DAFTAR PUSTAKA}

Februariyanti, H., \& Zuliarso, E. (2012). Rancang Bangun Sistem Perpustakaan untuk Jurnal Elektronik. Jurnal Teknologi Informasi Dinamik, 17(2), 124-132.

Herpendi, H. (2017). Aplikasi SMS-TI dengan VB. NET. Jurnal Sains Dan Informatika, 3(1), $27-32$.

Puspitasari, D. (2016). Sistem Informasi Perpustakaan Sekolah Berbasis Web. Jurnal Pilar Nusa Mandiri, 12(2), 227-240.

Raharja, U., Lutfiani, N., \& Wardana, W. S. (2018). Penjadwalan Agenda Pelaksanaan Tridharma Perguruan Tinggi Secara Online Menggunakan Google Calendar. Jurnal Teknoinfo, 12(2), 66-71.

Riyadi, A. S., Retnadi, E., \& Supriatna, A. D. (2012). Perancangan Sistem Informasi Berbasis Website Subsistem Guru di Sekolah Pesantren Persatuan Islam 99 Rancabango. Jurnal Algoritma, 9(40), 1-11.

Rosa, A. S., \& Shalahuddin, M. (2013). Rekayasa Perangkat Lunak Terstruktur dan Berorientasi Objek. Bandung: Informatika.

Sovia, R., \& Febio, J. (2011). Membangun Aplikasi E-Library Menggunakan Html, Php Script, Dan Mysql Database. Jurnal Processor, 6(2), 38-54.

\section{Biodata Penulis}

Herpendi, dilahirkan di Gunung Makmur, 20 November 1990. Tamat Sekolah Dasar (SD) Negeri Gunung Makmur 1, Takisung 2003. Sekolah Lanjutan Tingkat Pertama (SMP) diselesaikan tahun 2006 di SMPN 1 Takisung. Lulus Sekolah Menengah Kejuruan (SMK) 1 Negeri Tanah Laut tahun 2009. Tahun 2009 mulai kuliah di Universitas Kalimantan Muhammad Arsyad Al-Banjary dan lulus sarjana pada tahun 2013 dengan gelar S.Kom. Pendidikan pascasarjana (S-2) ditempuh tahun 2013 dan lulus tahun 2015 dengan gelar Magister Komputer (M.Kom). Menjadi Dosen Tetap di lingkungan Politeknik Negeri Tanah Laut terhitung Januari 2016.

Resni Habibah, lahir di Pelaihari pada tanggal 15 Juni 1998. Penulis pertama menyelesaikan Sekolah Menengah Atas di SMAN 1 Pelaihari pada tahun 2016 dan melanjutkan pendidikan ke Politeknik Negeri Tanah Laut. Saat ini penulis pertama telah menempuh semester VI di Jurusan Teknik Informatika Politeknik Negeri Tanah Laut dan sedang menyelesaikan Tugas Praktek Kerja Lapangan untuk memperoleh gelar A.Md. 